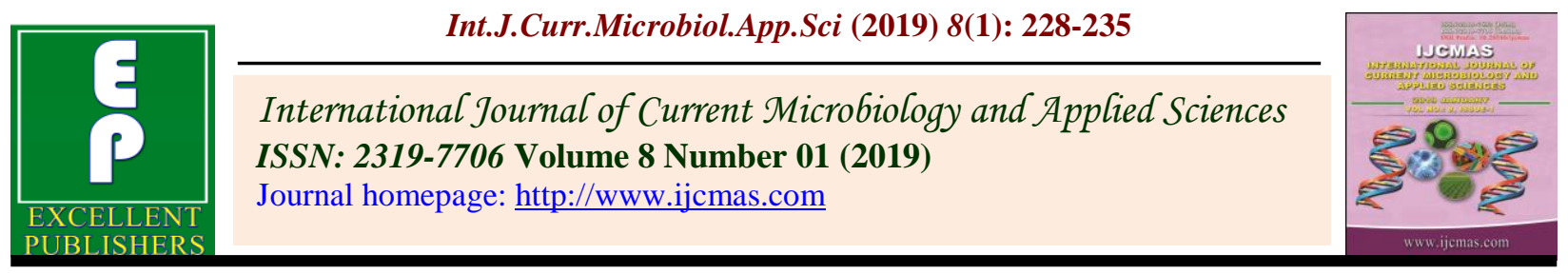

Original Research Article https://doi.org/10.20546/ijcmas.2019.801.026

\title{
Study the Relationship of BCS with Milk Composition and Reproductive Performance
}

\author{
Budhi Prakash Meena, Subhash Chander Goswami, Vijay Kumar, Arun Kumar \\ Jhirwal, Vikramjit Singh* and Vikas Sharma \\ Department of Livestock Production Management, \\ College of Veterinary and Animal Science, Rajasthan University of Veterinary and Animal \\ Sciences, Bikaner-334001, Rajasthan, India \\ *Corresponding author
}

Keywords

Reproductive performance, Kankrej, Significantly, Lactation, BCS

Article Info

Accepted: 04 December 2018 Available Online: 10 January 2019

\section{A B S T R A C T}

A total of 18 Kankrej cattle of $1^{\text {st }}$ to $4^{\text {th }}$ parity were selected for the study and distributed into three different groups based on their pre calving BCS (before 15 days of expected date of calving) namely G1(2.50 - 3.00), G2 (3.25 - 3.75) and G3 (4.00 and above) with six animals in each group. The average fortnight fat $\%$ in G1 was decreased up to $60^{\text {th }}$ day, remained same up to $75^{\text {th }}$ days and thereafter decreased, in G2 group decreased significantly $(\mathrm{P}<0.05)$ up to $60^{\text {th }}$ day and again increased up to $90^{\text {th }}$ day, where as in $\mathrm{G} 3$ group increased significantly $(\mathrm{P}<0.05)$ up to $60^{\text {th }}$ day and then decreased up to $90^{\text {th }}$ day. The average lactose \% was 4.40 \pm 0.09 in G3 group which were highest followed by in G2 and G1 group $4.27 \pm 0.009$ and $4.19 \pm 0.009$, respectively. The average TS content of milk changes with advance in lactation in G1 and G2 group animals, and were found to be non significant throughout the study period. The animals of G2 BCS group had shorter postpartum estrus period, a fewer services per conception, higher first service conception rate and a shorter service period followed by Kankrej cattle of G3 group and GI group. The studied revealed that BCS had a significant $(\mathrm{P}<0.05)$ effect on the reproductive performance in experimental animals.

\section{Introduction}

In early lactation the energy intake does not keep pace with continuously rising milk yield as a result energy deficit increases. This leads to a competitive situation among milk yield, fertility and health of the dairy cow because these traits are linked with energy requirement (Coenen, 2014). The various blood metabolites are used to measures the energy balance (EB) status in dairy animals, which has been reported to be strongly correlated with energy balance (Konigsson et al., 2000 and Clark et al., 2005). However, analyses of these blood metabolites are only feasible on experimental farms. Therefore, there is interest in other traits, which could serve as indicators of EB and may subsequently be related to the production and fertility status of an animal. Body condition score (BCS) is one 
of those 2 measures which is widely used in many species to assess body composition and energy status of animals (de Vries and Veerkamp, 2000 and Veerkamp et al., 2001).

\section{Materials and Methods}

Experimental design: Eighteen Kankrej cattle were distributed into three separate groups based on their pre-calving BCS (15 days before expected date of calving) namely $\mathrm{G}_{1}, \mathrm{G}_{2}$ and $\mathrm{G}_{3}$ with six animals in each group as shown in Table 1 .

\section{Parameters to be studied}

\section{Milk components}

The milk components, including fat, protein, lactose, total solids and Solid Not Fat (SNF), were studied in relation to BCS from calving to12 weeks postpartum at weekly intervals. The representative milk samples were collected from the milking bucket after complete milking of the individual animal. The milk samples were analyzed by auto analyzer.

\section{Reproductive parameter}

\section{Post partum estrus}

Post Partum estrus was observed by the acceptance of a male by the female, which is the most prominent and reliable symptoms of estrus.

\section{Service period}

The service period was calculated from the date of calving to date of successful service.

\section{Number of service per conception}

The data regarding number of service per conception was obtained from the record of the farm.

\section{First service conception rate}

The first service conception rate was calculated by the percentage of experimental cattle conceiving out of the total cattle at first service.

\section{Analysis of data}

The collected and tabulated data was analyzed by using SPSS 20.0.

\section{Results and Discussion}

\section{Milk composition}

\section{Fat $(\%)$}

The fortnight average fat per cent in milk of animals of each group are presented in the Table 2.

The average fortnight fat per cent in milk was decreased up to $60^{\text {th }}$ day and remained same up to $75^{\text {th }}$ day and thereafter increased up to $90^{\text {th }}$ day in G1 group of animals, which was found significantly from $15^{\text {th }}$ to $45^{\text {th }}$ day, thereafter non-significant up to $90^{\text {th }}$ day.

The average fortnight fat per cent in milk of G2 group of animals, decreased up to $60^{\text {th }}$ day but significantly $(\mathrm{P}<0.05)$ up to 30 and increased up to $75^{\text {th }}$ day and again decreased up to 90th day, which was found to be non significant.

The average fortnight fat per cent in milk of G3 group animals, decreased significantly $(\mathrm{P}<0.05)$ up to $60^{\text {th }}$ day then after decreased up to $90^{\text {th }}$ day which was found to be non significant.

The average fat per cent significantly $(\mathrm{P}<0.05)$ differed between the G1 and G2, G3 groups throughout the study period. There was G2 and G3 group non-significant throughout the 
study period. The G3 and G2 group animals had the highest fat percent in the milk followed by G1 group animal $3.54 \pm 0.07$, $3.86 \pm 0.068$ and $3.86 \pm 0.065 \%$, respectively.

Similar finding were reported by Prasad and Tomar (1996). Berry et al., (2007), Musthaq (2010) in Nili Ravi buffalo, Janus et al., (2012) in H.F. cow, and Singh et al., (2015) in H.F. cows.

\section{Solid Not Fat \% (SNF \%)}

The average fortnightly Solid Not Fat per cent in milk of Kankrej cattle with different BCS groups are presented in Table 3.

The average fortnight SNF percent in the milk of G1 group animals was found significant between $45^{\text {th }}$ to $60^{\text {th }}$ days and G2 group animals was found to be non significant throughout the study period except $30^{\text {th }}$ and $45^{\text {th }}$ days.

The average fortnight SNF per cent in milk of G3 group animals, decreased up to $90^{\text {th }}$ day, which was found to be non significant throughout the study period except $15^{\text {th }}, 30^{\text {th }}$ and $45^{\text {th }}$ day. .

The fortnight average SNF per cent were found to be significant between the groups in $45^{\text {th }}$ days of lactation, thereafter G1 and G2 group was found to be non significant in between group but both groups were significant with G3 group.

There was significant $(\mathrm{P}<0.05)$ difference in fortnight average SNF percent between the three groups throughout the study period.

In G3 group of animals the SNF per cent was $8.74 \pm 0.05$ which was highest among all the groups and in the G2 and G1 group of animals the corresponding values were $8.67 \pm 0.05$ and $8.61 \pm 0.05$, respectively. Similar findings were reported by Prasad and Tomar (1996), Musthaq (2010) in Nili Ravi buffalo and Janus et al., (2012) in H.F. cows.

\section{Protein (\%)}

The fortnight average protein per cent in milk of Kankrej cattle with different BCS groups are presented in Table 4.

The average fortnight protein per cent in milk of G1 group of animals increased up to $45^{\text {th }}$ day and thereafter decreased up to $60^{\text {th }}$ day, and after that there was gradual increase in protein per cent up to $90^{\text {th }}$ day, which were found to be non significant.

The fortnight average protein per cent in milk of $\mathrm{G} 2$ group animals increased up to $30^{\text {th }}$ day and thereafter decreased up to $60^{\text {th }}$ day then again increased up to $75^{\text {th }}$ day after that remained same up to $90^{\text {th }}$ day, which were found to be non significant.

The fortnight average protein per cent milk of G3 group animals, increase significantly $(\mathrm{P}<0.05)$ up to $60^{\text {th }}$ day, and afterward decreased up to $75^{\text {th }}$ day and remained same up to $90^{\text {th }}$ day.

There was significant $(\mathrm{P}<0.05)$ difference in fortnight average protein percent between the three groups throughout the study period. The average protein per cent was 3.60 \pm 0.05 in G3 group which were highest followed by $3.32 \pm 0.05$ and $3.16 \pm 0.05$, respectively in $\mathrm{G} 2$ and $\mathrm{G} 1$ group.

Similar findings were reported by Prasad and Tomar (1996), Musthaq (2010) in Nili Ravi buffalo, Janus et al., (2012) in H.F. cows. However, Treacher et al., (1986) reported that during early lactation, the group of fat (BCS 4) cows had yielded less milk protein than the group of thin (BCS 2.5) cows which is in disagreement with present study. 


\section{Lactose (\%)}

The fortnight average lactose per cent in milk of Kankrej cattle with different BCS groups are presented in Table 5.

The average fortnightly lactose per cent in milk of G1 group of animals decreased up to $30^{\text {th }}$ day and afterward increased up to $60^{\text {th }}$ day and then again decreased up to $90^{\text {th }}$, which was found to be non significant. The average fortnightly lactose percent in milk of G2 group of animals, decreased up to $30^{\text {th }}$ day and afterward increased up to $60^{\text {th }}$ day and decreased up to $75^{\text {th }}$ day afterward remain same up to $90^{\text {th }}$ day, which was found to be non significant.

Table.1 Grouping of the cattle based on their pre-calving BCS

\begin{tabular}{|l|c|c|}
\hline $\begin{array}{l}\text { Grouping of the cattle based on } \\
\text { their pre-calving BCS Groups }\end{array}$ & No. of animals & BCS \\
\hline $\mathbf{G}_{\mathbf{1}}$ & 6 & $2.50-3.00$ \\
\hline $\mathbf{G}_{\mathbf{2}}$ & 6 & $3.25-3.75$ \\
\hline $\mathbf{G}_{\mathbf{3}}$ & 6 & 4.00 and above \\
\hline
\end{tabular}

Table.2 Average fortnightly fat (\%) in milk of Kankrej cattle with different BCS groups

\begin{tabular}{|l|c|c|c|}
\hline \multirow{2}{*}{$\begin{array}{l}\text { Fortnight } \\
\text { Intervals (days) }\end{array}$} & \multicolumn{3}{|c|}{ Average Fat (\%) of animals in BCS groups } \\
\cline { 2 - 4 } $\mathbf{1 5}$ & $\mathbf{G 1}$ & $\mathbf{G} 2$ & $\mathbf{G 3}$ \\
\hline $\mathbf{3 0}$ & $3.71^{\mathrm{aC}} \pm 0.01$ & $3.97^{\mathrm{bC}} \pm 0.02$ & $4.13^{\mathrm{CD}} \pm 0.01$ \\
\hline $\mathbf{4 5}$ & $3.55^{\mathrm{aB}} \pm 0.03$ & $3.90^{\mathrm{bB}} \pm 0.05$ & $4.01^{\mathrm{CC}} \pm 0.06$ \\
\hline $\mathbf{6 0}$ & $3.51^{\mathrm{aA}} \pm 0.02$ & $3.86^{\mathrm{BAB}} \pm 0.06$ & $3.83^{\mathrm{bB}} \pm 0.05$ \\
\hline $\mathbf{7 5}$ & $3.50^{\mathrm{aA}} \pm 0.02$ & $3.83^{\mathrm{bA}} \pm 0.04$ & $3.77^{\mathrm{CA}} \pm 0.06$ \\
\hline $\mathbf{9 0}$ & $3.50^{\mathrm{aA}} \pm 0.02$ & $3.84^{\mathrm{bA}} \pm 0.05$ & $3.74^{\mathrm{CA}} \pm 0.04$ \\
\hline Total (Average) & $3.52^{\mathrm{aAB}} \pm 0.01$ & $3.82^{\mathrm{bA}} \pm 0.04$ & $3.72^{\mathrm{CA}} \pm 0.04$ \\
\hline
\end{tabular}

Different superscript in a column (capital letter A, B, C) differ significantly ( $\mathrm{p}<0.05$ ),

Different superscript in a row (small letter a, b, c) differ significantly $(\mathrm{p}<0.05)$.

Table.3 Fortnightly average solid not fat (\%) in milk of Kankrej cattle with different BCS groups

\begin{tabular}{|l|c|c|c|}
\hline \multirow{2}{*}{$\begin{array}{l}\text { Fortnight } \\
\text { Intervals (days) }\end{array}$} & \multicolumn{3}{|c|}{ Average SNF (\%) of animals in BCS groups } \\
\hline $\mathbf{1 5}$ & $\mathbf{G 1}$ & $\mathbf{G}$ & $\mathbf{G 3}$ \\
\hline $\mathbf{3 0}$ & $8.60^{\mathrm{aA}} \pm 0.01$ & $8.70^{\mathrm{bA}} \pm 0.01$ & $8.77^{\mathrm{CC}} \pm 0.01$ \\
\hline $\mathbf{4 5}$ & $8.60^{\mathrm{aA}} \pm 0.03$ & $8.70^{\mathrm{bB}} \pm 0.04$ & $8.76^{\mathrm{CBC}} \pm 0.02$ \\
\hline $\mathbf{6 0}$ & $8.57^{\mathrm{aA}} \pm 0.04$ & $8.68^{\mathrm{bAB}} \pm 0.05$ & $8.74^{\mathrm{CAB}} \pm 0.02$ \\
\hline $\mathbf{7 5}$ & $8.64^{\mathrm{aB}} \pm 0.03$ & $8.66^{\mathrm{aA}} \pm 0.04$ & $8.73^{\mathrm{bA}} \pm 0.02$ \\
\hline $\mathbf{9 0}$ & $8.65^{\mathrm{aB}} \pm 0.03$ & $8.66^{\mathrm{aA}} \pm 0.05$ & $8.72^{\mathrm{bA}} \pm 0.02$ \\
\hline Total (Average) & $8.66^{\mathrm{aC}} \pm 0.03$ & $8.66^{\mathrm{aA}} \pm 0.05$ & $8.71^{\mathrm{bA}} \pm 0.02$ \\
\hline
\end{tabular}

Different superscript in a column (capital letter A, B, C) differ significantly ( $\mathrm{p}<0.05)$,

Different superscript in a row (small letter a, b, c) differ significantly $(\mathrm{p}<0.05)$ 
Table.4 Fortnightly average Protein (\%) in milk of Kankrej cattle with different BCS groups

\begin{tabular}{|l|c|c|c|}
\hline \multirow{2}{*}{$\begin{array}{l}\text { Fortnight } \\
\text { Intervals (days) }\end{array}$} & \multicolumn{3}{|c|}{ Average Protein (\%) of animals in BCS groups } \\
\hline $\mathbf{1 5}$ & G1 & G2 & G3 \\
\hline $\mathbf{3 0}$ & $3.14^{\mathrm{aA}} \pm 0.01$ & $3.30^{\mathrm{bA}} \pm 0.01$ & $3.54^{\mathrm{cA}} \pm 0.01$ \\
\hline $\mathbf{4 5}$ & $3.15^{\mathrm{aA}} \pm 0.02$ & $3.34^{\mathrm{bA}} \pm 0.02$ & $3.57^{\mathrm{CA}} \pm 0.03$ \\
\hline $\mathbf{6 0}$ & $3.17^{\mathrm{aA}} \pm 0.02$ & $3.32^{\mathrm{bB}} \pm 0.01$ & $3.62^{\mathrm{CA}} \pm 0.05$ \\
\hline $\mathbf{7 5}$ & $3.16^{\mathrm{aAB}} \pm 0.01$ & $3.30^{\mathrm{bAB}} \pm 0.01$ & $3.64^{\mathrm{cB}} \pm 0.04$ \\
\hline $\mathbf{9 0}$ & $3.17^{\mathrm{aA}} \pm 0.02$ & $3.34^{\mathrm{bA}} \pm 0.02$ & $3.63^{\mathrm{CB}} \pm 0.04$ \\
\hline Total (Average) & $3.20^{\mathrm{aAB}} \pm 0.02$ & $3.34^{\mathrm{bAB}} \pm 0.02$ & $3.63^{\mathrm{CB}} \pm 0.05$ \\
\hline
\end{tabular}

Different superscript in a column (capital letter A, B) differ significantly $(\mathrm{p}<0.05)$,

Different superscript in a row (small letter $a, b, c)$ differ significantly $(p<0.05)$

Table.5 Fortnightly average Lactose (\%) in milk of Kankrej cattle with different BCS groups

\begin{tabular}{|l|c|c|c|}
\hline \multirow{2}{*}{$\begin{array}{l}\text { Fortnight } \\
\text { Intervals (days) }\end{array}$} & \multicolumn{3}{|c|}{ Average Lactose (\%) of animals in BCS groups } \\
\cline { 2 - 4 } & G1 & G2 & G3 \\
\hline $\mathbf{1 5}$ & $4.20^{\mathrm{aA}} \pm 0.01$ & $4.29^{\mathrm{bA}} \pm 0.01$ & $4.47^{\mathrm{cB}} \pm 0.01$ \\
\hline $\mathbf{3 0}$ & $4.19^{\mathrm{aA}} \pm 0.03$ & $4.27^{\mathrm{bA}} \pm 0.02$ & $4.45^{\mathrm{cB}} \pm 0.01$ \\
\hline $\mathbf{4 5}$ & $4.20^{\mathrm{aA}} \pm 0.03$ & $4.28^{\mathrm{bA}} \pm 0.02$ & $4.43^{\mathrm{cB}} \pm 0.01$ \\
\hline $\mathbf{6 0}$ & $4.21^{\mathrm{aA}} \pm 0.02$ & $4.29^{\mathrm{bA}} \pm 0.02$ & $4.48^{\mathrm{cB}} \pm 0.01$ \\
\hline $\mathbf{7 5}$ & $4.20^{\mathrm{aA}} \pm 0.02$ & $4.27^{\mathrm{bA}} \pm 0.02$ & $4.45^{\mathrm{cB}} \pm 0.02$ \\
\hline $\mathbf{9 0}$ & $4.18^{\mathrm{aA}} \pm 0.02$ & $4.27^{\mathrm{bA}} \pm 0.02$ & $4.17^{\mathrm{cB}} \pm 0.02$ \\
\hline Total (Average) & $4.19^{\mathrm{a}} \pm 0.009$ & $4.27^{\mathrm{b}} \pm 0.009$ & $4.40^{\mathrm{C}} \pm 0.09$ \\
\hline
\end{tabular}

Different superscript in a column (capital letter A, B, C) differ significantly ( $\mathrm{p}<0.05$ ),

Different superscript in a row (small letter $a, b, c)$ differ significantly $(p<0.05)$

Table.6 Average fortnightly total solid (\%) in milk of Kankrej with different BCS groups

\begin{tabular}{|l|c|c|c|}
\hline \multirow{2}{*}{$\begin{array}{l}\text { Fortnight } \\
\text { Intervals (days) }\end{array}$} & \multicolumn{3}{|c|}{ Average Total solids (\%) of animals in BCS groups } \\
\cline { 2 - 4 } $\mathbf{1 5}$ & $\mathbf{G 1}$ & $\mathbf{G 2}$ & $\mathbf{G 3}$ \\
\hline $\mathbf{3 0}$ & $12.3^{\mathrm{a} C} \pm 0.01$ & $12.66^{6 \mathrm{D}} \pm 0.02$ & $12.89^{\mathrm{CD}} \pm 0.01$ \\
\hline $\mathbf{4 5}$ & $12.15^{\mathrm{aB}} \pm 0.02$ & $12.60^{\mathrm{bC}} \pm 0.02$ & $12.76^{\mathrm{CC}} \pm 0.02$ \\
\hline $\mathbf{6 0}$ & $12.07^{\mathrm{aB}} \pm 0.01$ & $12.53^{\mathrm{aA}} \pm 0.02$ & $12.56^{\mathrm{aA}} \pm 0.02$ \\
\hline $\mathbf{7 5}$ & $12.14^{\mathrm{aB}} \pm 0.01$ & $12.49^{\mathrm{BA}} \pm 0.01$ & $12.49^{\mathrm{bA}} \pm 0.08$ \\
\hline $\mathbf{9 0}$ & $12.14^{\mathrm{aB}} \pm 0.01$ & $12.49^{\mathrm{bA}} \pm 0.02$ & $12.45^{\mathrm{CA}} \pm 0.01$ \\
\hline Total (Average) & $12.17^{\mathrm{aB}} \pm 0.01$ & $12.47^{\mathrm{b}} \pm 0.02$ & $12.42^{\mathrm{bA}} \pm 0.01$ \\
\hline
\end{tabular}

Different superscript in a column (capital letter A, B, C, D) differ significantly ( $<<0.05)$,

Different superscript in a row (small letter a, b, c) differ significantly $(\mathrm{p}<0.05)$ 
Table.7 The reproductive performances in Kankrej cattle with different BCS groups

\begin{tabular}{|r|l|c|c|c|}
\hline S.No. & Reproductive traits & \multicolumn{3}{|c|}{ BCS groups } \\
\cline { 3 - 5 } & & \multicolumn{1}{|c|}{ G1 } & G2 & G3 \\
\hline $\mathbf{1 .}$ & $\begin{array}{l}\text { Post-partum estrus } \\
\text { (days) }\end{array}$ & $102^{\mathrm{c}} \pm 3.91$ & $66.67^{\mathrm{a}} \pm 1.62$ & $83.17^{\mathrm{b}} \pm 1.83$ \\
\hline $\mathbf{2 .}$ & $\begin{array}{l}\text { No. of service per } \\
\text { conception }\end{array}$ & $2.17^{\mathrm{b}} \pm 0.30$ & $1.34^{\mathrm{a}} \pm 0.21$ & $1.50^{\mathrm{a}} \pm 0.22$ \\
\hline $\mathbf{3 .}$ & $\begin{array}{l}\text { First service conception } \\
\text { rate }(\%)\end{array}$ & $16.67^{\mathrm{a}} \pm 16.66$ & $66.67^{\mathrm{b}} \pm 21.08$ & $50.00^{\mathrm{b}} \pm 22.36$ \\
\hline 4. & Service period (Days) & $147.5^{\mathrm{c}} \pm 7.36$ & $91.34^{\mathrm{a}} \pm 4.11$ & $114.67^{\mathrm{b}} \pm 3.48$ \\
\hline
\end{tabular}

Different superscript in a row (small letter $a, b, c)$ differ significantly $(p<0.05)$

In G3 group of animals, the average fortnight lactose percent in milk decreased up to $45^{\text {th }}$ day and afterward increased up to $60^{\text {th }}$ day afterward again decreased up to $90^{\text {th }}$ day, which was found to be non significant.

There was significant $(\mathrm{P}<0.05)$ difference in fortnight average lactose percent between the three groups throughout the study period. The average lactose $\%$ was $4.40 \pm 0.09$ in G3 group which were highest followed by in G2 and G1 group $4.27 \pm 0.09$ and $4.19 \pm 0.09$, respectively.

Similar findings were reported by Musthaq (2010) in Nili Ravi Buffalo, and Janus et al., (2012) in H.F. cows

However, Treacher et al., (1986) reported that during early lactation, the group of fat (BCS 4) cows had yielded less lactose than the group of thin (BCS 2.5) cows which is in disagreement with present study.

\section{Total solid (\%)}

The fortnight average total solids per cent in milk of Kankrej cattle with different BCS groups are presented in Table 6 . The fortnight average total solids differ significantly $(\mathrm{P}<0.05)$ in milk of Kankrej cattle among different BCS groups. The average TS content of milk changes with advance in lactation in
G1 and G2 group of animals, and were found to be non significant throughout the study period.

The fortnight average TS per cent in milk of G3 group of animals decreased up to $90^{\text {th }}$ day, but the decrease was significant $(\mathrm{P}<0.05)$ up to $45^{\text {th }}$ day.

There was significant $(\mathrm{P}<0.05)$ difference in TS per cent in the milk of G1, G2 and G3 groups throughout the study period. The average TS per cent were $12.60 \pm 0.03 \%$ in G3 group animals which were highest followed by in G2 and G1 group with $12.54 \pm 0.01 \%$ and $12.16 \pm 0.01 \%$, respectively.

Similar findings were reported by Janus et al., (2012).

\section{Reproductive performance}

The reproductive performances in Kankrej cattle with different BCS groups are presented in Table 7.

Table revealed that the animals of G2 group had shorter postpartum estrus period, fewer services per conception, higher first service conception rate and shorter service period and the values for corresponding parameter were $66.67 \pm 1.62$ days, $1.34^{\mathrm{a}} \pm 0.21,66.67$ per cent 
and 91.34 \pm 4.11 days, respectively. The Kankrej cattle of G3 group had $83.17 \pm 1.83$ days, $\quad 1.50 \pm 0.22, \quad 50.00$ percent and $114.67^{\mathrm{b}} \pm 3.48$ respectively for post-partum estrus, number of service per conception, first service conception rate and service period. Whereas Kankrej cattle of G1 group had $102 \pm 3.91$ days, $2.17 \pm 0.30,16.67$ per cent and $147.5 \pm 7.36$ days respectively for post-partum estrus, number of service per conception, first service conception rate and service period. The study revealed that BCS had significant $(\mathrm{P}<0.05)$ effect on all the reproductive traits under the study.

Similar findings were reported by Gillund et al., (2001) in Norvegian cattle, Buckley et al., (2003) in H.F. cows, Rochey et al., (2009), in dairy cow, Bayram et al., (2008) in Swedish Red and White cows, Rao and Anitha (2013) in buffalo and Stadnik et. al., (2017) in Czech Fleckvieh cows.

\section{Acknowledgement}

The authors thankfully acknowledged the financial support and facilities provided by RAJUVAS, Bikaner to carry out the research work.

\section{References}

Bayram, B., Yanar, M. and Akbulut, O. 2008. Reproductive and milk production traits of Holstein Friesian cows in pre-organic and organic dairy husbandry in Turkey. Journal of Animal and Veterinary Advances. 7(7): 808-811.

Buckley, F., Sullivan, K., Mee, J. F., Evans, R. D. and Dillon, P. 2003. Relationships among milk yield, body condition, cow weight, and reproduction in springcalved Holstein-Friesians. Journal of Animal Science. 86(7): 2308-2319.

Berry, D. P. Buckley, F. and Dillon, P. 2007. Body condition score and live-weight effects on milk production in Irish Holstein-Friesian dairy cows. Animal. 1(9): 1351-1359.

Clark, C. E. F., Fulkerson, W. J., Nandra, K. S., Barchia, I. and Macmillan, K. L. 2005. The use of indicators to assess the degree of mobilization of body reserves in dairy cows in early lactation on a pasture-based diet. Livestock Production Science. 94: 199-211.

Coenen, H. and Peter, M. S. 2014. Associations among body condition score, body weight, and milk weight in crossbred dairy cattle in a confined dairy operation. Tarleton State University.

DeVries, M. J. and Veerkamp, R. F. 2000. Energy balance of dairy cattle in relation to milk production variables and fertility. Journal of Dairy Science. 83:62-69.

Gillund, P., Reksen, O., Grohn, Y. T. and Karlberg, K. 2001. Body condition related to ketosis and reproductive performance in norwegian dairy cows. Journal of Dairy Science. 84(6): 13901396.

IBM SPSS STATISTICS VERSION; 20.

Janus, E. and Borkowska, D. 2012. Changes of body condition of cows, daily milk yield and its composition during the course of lactation. Rocz Nauk. 1(1): 7584.

Konigsson, K., Savoini, G., Govoni, N., Invernizzi, G., Prandi, A., Kindahl. H. and Veronesi, M. C. 2000. Energy balance, leptin, NEFA and IGF-I plasma concentrations and resumption of postpartums ovarian activity in Swedish red and white breed cows. Acta Veterinaria Scandinavica. 50(3): 1-7.

Mushtaq, A. 2010. Effect of Physiological states on milk fatty acids profile In dairy cows and buffaloes. Ph.D. Thesis, (Livestock production and management), North-West Frontier 
Province, Agricultural University, Stadnik, L., Atasever, S. and Duchacek, J. Peshawar. 2017. Effects of body condition score and daily milk yield on reproduction traits of Czech Fleckvieh cows. Animal Reproduction. 14(1): 1264-1269.

Condition Score (BCS) system in Murrah buffaloes. Buffalo Bulletin. 32: 1290-1298.

Roche, J. R., Friggens N. C., Stockdale, C. R., Baumgard, L. H., VanBaale, M. H. and Berry, D. P. 2009. Body condition score and its association with dairy cow productivity, health, and welfare. Journal of Dairy Science. 92(12): 57695801.

Singh, V., Singh, V. K., Singh, S. P. and Sahoo, B. 2015. The effect of body score condition at calving on milk yield, milk composition and udder health status of dairy animals. Journal of dairy, Veterinary and Animal Research. 2(2): 22

Thomas, C. K. and Sastry, N. S. R. 2012. Dairy Bovine Production, 2nd revised Edn., Kalyani Publishers, New Delhi, India.

Treacher, R. J., Roberts, C. J. and Tomas, J. 1986. Effect of body condition on reproductive performance in dairy cows. Animal Production. 79: 11-16.

Veerkamp, R. F., Koenen, E. P. C. and DeJong, G. 2001. Genetic correlations among Body condition score, yield, and fertility in 1st parity cows estimated by random regression models. Journal of Dairy Science. 84: 2327-2335.

\section{How to cite this article:}

Budhi Prakash Meena, Subhash Chander Goswami, Vijay Kumar, Arun Kumar Jhirwal, Vikramjit Singh and Vikas Sharma. 2019. Study the Relationship of BCS with Milk Composition and Reproductive Performance. Int.J.Curr.Microbiol.App.Sci. 8(01): 228-235. doi: https://doi.org/10.20546/ijcmas.2019.801.026 